\title{
RICH AS A BORROWER
}

$\mathrm{E}$

VEN in a day when plagiarism was not yet a word, let alone a sort of crime, and when few put pen to paper without first canvassing and tapping assorted models, the extent of Rich's borrowings was prodigious. So it must have seemed to Rich himself: as if prompted by a queasy conscience, he felt obliged to comment on the subject in a prefatory section of his first publication. "Although, gentle Reader," he freely and disarmingly confesses in $A$ Right Exelent and Pleasaunt Dialogue, betwene Mercury and an English Souldier (I574), "I haue done as the Iay, who decked her selfe with the fethers of other Byrds, to the ende, she might seeme to be the more glorious, yet I doubte not but if euery Byrd should pluck his fether from this my deuise, it would not be left altogither destitute, nor so vtterly naked, but ther would yet remayne something worthy to be perused."

Plucking and identifying the feathers which adorn the five stories in the Faremell (the first, second, fifth, seventh, and eighth) which are not adapted from Cinthio's Italian is both a diverting and an instructive exercise. The catalogue of discoverable sources, Continental and English, shows that verse and drama as well as prose were grist to Rich's mill. Clearly demonstrable are his debts to Painter, Pettie, Gascoigne, Lyly, Udall, Golding, Underdowne, Cinthio, Belleforest, and Straparola. ${ }^{1}$ Why other authors of Elizabethan best-sellers published before I58I do not appear on this list may be explained by Rich's revelation "To the gentle and friendly Reader" of his second book, the Allarme to England of 1578 , a year when he was probably engaged in writing the Farewell: "Surely I must confesse I haue vsed the helpe of sundrie writers, but not of so many as I would haue done, if I had bene in place where I might haue come by them: for what I haue written, was onely done in Ireland, where there is no great choyce of bookes to be had."

The books that did somehow find their way to that literary desert

I Specific borrowings are indicated in my notes, as in those to 48. 7-28 and 87. 27-36 (such references are to pages and lines of the facsimile text). The sources of each of the tales not adapted from Cinthio are discussed below, pp. 339-50. 
xviii

\section{INTRODUCTION}

island, to serve such castaways as Rich, Bryskett, Fenton, and Spenser as intellectual pabulum, must have reflected a fairly careful choice. Presumably, then, the sources that went into the making of the Farewell, also composed in Ireland, so Rich confides (10. I9 f.), provide an interesting, though doubtless incomplete, index to what the exiles deemed of special value as entertainment and literature and therefore worth importing.

The scarcity of books at Rich's disposal may account for the fact that he worked certain of his sources overtime. Painter's Palace never failed him when he required help in christening a hero, delineating a character, evolving a plot, or, above all, constructing dialogue and soliloquy. Obviously convinced that Painter's rhetoric was more elegant than anything he himself could devise, he transferred torrents of words from the Palace to the Farewell. Of Painter's Ior stories, more than two dozen, a not unimpressive proportion of the total, are represented in Rich by borrowings great and small. These are not distributed evenly throughout the Faremell. Painter's hold on Rich is unrelenting in the first tale (where it is discernible on thirty-three of the forty-three printed pages), still powerful in the second, and substantial in the fifth, but almost negligible in the seventh and eighth.

As Painter's influence waned, Pettie's waxed. Rich used all twelve of the stories in the Petite Pallace, not to mention the introductory sections. Verbal echoes of Pettie are slight though unmistakable in the first story, louder in the second, reverberating in the fifth, and thunderous in the eighth. Apart from words and bits of plot and characterization in the Petite Pallace, there were, of course, to be emulated Pettie's famous attitude toward the ladies in his audience and his style, and the influence of these on the Farewell is pervasive. Dozens of passages, some lifted verbatim from the Petite Pallace, others composed with one eye on Pettie's page, are so dotted with alliteration, antithesis, and proverbial lore as to suggest that Rich regarded felicity of style and Pettie's brand of euphuism as practically synonymous. Like Pettie, moreover, he is much given to interrupting his narrative (as at 84.5 ) to smirk at his gentlewomen readers and to offer-in a tone now confidential and insinuating, now coy, now saucy-arch commentaries on the action.

His surprisingly wholesale borrowings from Painter and Pettie may be due as much to necessity as to choice. Since in Ireland he was, by his 


\section{RICH AS A BORROWER}

own admission, poor in books available for ransacking, why should he not make the greatest use of what few he had ? Such a need for economy would also explain his treatment of other sources. Several stories in Belleforest and Cinthio were made to do double or even triple dutyBelleforest's melancholy "The Lady of Chabry," for instance. After translating and printing this particular story as part of his first book in 1574, Rich then turned to his own translation for substantial help in writing the first, second, and fifth tales in the Faremell. In like fashion, Cinthio's "Cesare Gravina" supplied certain details of plot for the first story in the Farewell, while certain others, unused in the first but apparently husbanded with remarkable care, appear in the last. From Belleforest's story of Nicole and from the Eustace-Placidas legend Rich also wrung an uncommon amount of service; the former is a principal source of both "Apolonius" and "Phylotus," the latter of both "Sappho" and "Apolonius." Thus ingenuity meliorates poverty: even not quite enough may be as good as a feast.

However limited Rich may have thought his raw materials to be, they are nevertheless profuse, complicated, and unwieldy enough to inspire wonder that they could have been reduced to any convenient, usable order. When Rich "forged" a story, to use a word with which he himself aptly describes (19. 13) his method of composition, he was in effect fusing elements from a welter of sources into a tale of his own. Instead of scurrying through the pages of a dozen models, selecting here a bit of plot, there a character, and there an appropriate speech, he resorted to a commonplace book, that invaluable aid without which few Elizabethans ventured to engage in composition. Scores of items that Rich clearly committed to his notebook and transferred thence to the Farewell are identifiable; but specific sources await detection for others (those beginning at 120. 3 I and 47. 5, for example) which are also evidently gems of the commonplace book. As Rich readily confesses (205. 3I-33), he was himself unable to recall from time to time precisely where and when he had gleaned this or that incident. But what could such lapses of memory matter to a tireless, unashamed borrower who, though eclecticism and improvement of his models may have been of some concern to him, was primarily interested in "forging" a good tale?

To read in order the five stories Rich says he "forged onely for delight" is to discover that his technique in "forging" improved with 


\section{INTRODUCTION}

practice. "Sappho," the first selection in the Faremell and probably Rich's first essay at writing an "original" tale, contains faults that betray him as a beginner. Its length, caused partly by the some two dozen lengthy sources which went into its making, seems exorbitant, the transitions from one section of the plot to another (as at 35. 12-22) gauche, and the interruptions of the narrative with homilies or endless amatory debates tiresome. So Rich himself regarded them, for he apologizes (at 24. 2530 and $67.28-33$ ) for his prolixity and discursiveness. These blemishes may have offended his contemporaries less than he feared, since no unhurried Elizabethan who could placidly make his way through such fiction as the Aethiopica and the Arcadia was likely to be disconcerted by a tale a mere sixty-three pages long. And the flights of rhetoric in a homiletic or amatory vein that strike the twentieth-century reader as unbearably grandiloquent doubtless impressed the Elizabethan as morally and stylistically grand.

"Apolonius," the second tale, is neither the most nor least attractive in Rich's collection, though as the source of Twelfth Night it is certainly the best known. From twenty-odd tales Rich was able with reasonable deftness to devise a narrative of his own that is marred little by the faults which beset "Sappho." On the contrary, "Apolonius" is often characterized by sprightliness and charm. Even so, Rich became a "forger" of remarkable suavity and finesse only in his fifth story, "Two Brethren." The casual reader of the Farewell in search of entertainment would be well advised to begin with this story rather than with "Sappho." Here Rich was a highly competent, even adroit, borrower, felicitous in both the choice and the adaptation of his eight sources, and the result of his skill is a tale as hilarious as the best of the French fabliaux.

The soberer seventh "history," "Aramanthus," is evidently the most original of Rich's eight tales; it depends on only three models that have been identified with certainty. The paucity of sources probably accounts both for the brevity of "Aramanthus" and for its unity, qualities for which Rich's other tales are not particularly distinguished. That Rich employed only three discoverable sources in writing it suggests that as he gained experience in storymaking he also gained confidence and was willing to rely less on others, more on his own resources. He manipulated the three sources he chose, however, with the same technical pro- 


\section{RICH AS A BORROWER}

ficiency which he exhibited in "Two Brethren" and was to display again in "Phylotus," the eighth and final tale. This rollicking, richly comic narrative is a smooth blend of such widely diverse ingredients as two histoires by Belleforest, novelle by Cinthio and Straparola, a story from Golding's Ovid, five stories by Pettie, and a play by Gascoigne. Yet this formidable lot of sources, which would perhaps have confused the relatively artless, inexperienced author of "Sappho" with their number and variety, failed to daunt the author of "Phylotus." No longer apprentice or journeyman, he left upon the last tale in the Faremell the stamp of the master "forger." 